\title{
CENA DE CARACTERES NA ÉPICA ARCAICA E NA TRAGÉDIA GREGA CLÁSSICA ${ }^{1}$
}

SCENE OF CHARACTERS IN THE ARCAIC EPIC AND CLASSIC GREEK TRAGEDY

\section{Marco Valério Classe Colonnelli}

Universidade Federal da Paraíba

João Pessoa - Brasil

\begin{abstract}
This article investigated the use of a narrative technique present in the Homeric epic and Euripides' tragedy Iphigenia in Aulis, in order to demonstrate the effects produced by such technique. The result of the investigation pointed out not only the difference between the epic and tragic narrative levels, but also the production of a particular narrative framework in both narratives: the scene of characters.
\end{abstract}

Keywords: Description, tragedy, epic, characterization, Homer, Euripides.

\section{Resumen}

En este trabajo se investigó el uso de una técnica narrativa en la épica homérica y la tragedia Ifigeniaen Áulide, de Eurípides, com el fin de demostrar los efectos producidos por dichos medios. El resultado de la investigación apuntó no solo la diferencia entre los niveles narrativos épico y trágico, sino también la producción de um cuadro narrativo específico en ambas narrativas: la escena de personajes.

Palabras claves: Descripción, tragedia, épica, caracterización, Homero, Eurípides.

\section{Resumo}

Este artigo investigou o uso de uma técnica narrativa presente na épica homérica e na tragédia Ifigênia em Aulis, de Eurípides, a fim de demonstrar os efeitos produzidos por tal expediente. O resultado da investigação apontou não só a diferença entre os níveis narrativos épico e trágico, mas também a produção de um quadro narrativo específico em ambas narrativas: a cena de caracteres.

Palavras-chave: Descrição, tragédia, épica, caracterização, Homero, Eurípides.

1 Todas as traduções foram feitas pelo autor do artigo, salvo onde está indicado o tradutor. 
Nas consideraçóes sobre a narrativa que encontramos em Platão e Aristóteles, há semelhanças muito estreitas entre as concepçôes de cada filósofo. Na República de Platão, a narração é uma parte específica da elocução poética

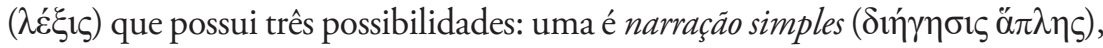

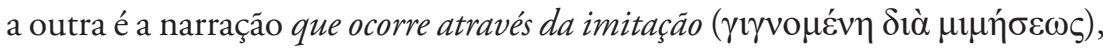

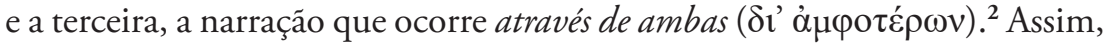
discorrendo sobre a natureza da elocução, o filósofo argumenta que Homero, no canto I, expressa tanto os acontecimentos, em uma narração indireta, quanto a fala das personagens, em discurso direto. Essas duas elocuçóes $(\lambda \varepsilon \dot{\varepsilon} \xi \varepsilon 1 \varsigma)$ constituem a base de sua teoria. Para ele, Homero, quando apresenta

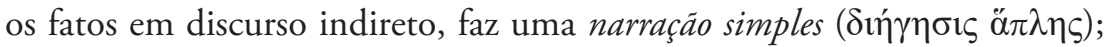
porém, quando narra o discurso das personagens através do discurso direto,

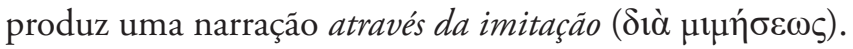

Aristóteles, na Poética, analisa a maneira pela qual um poeta produz a imitação poética. Ele também reconhece uma imitação narrativa ( $\alpha \dot{\alpha} \alpha \gamma \gamma \varepsilon \lambda i ́ \alpha)$,

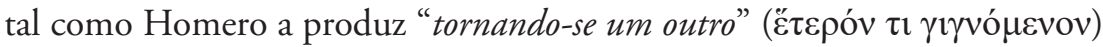
ou "como ele próprio e náo mudando" ( e outra sem alternância e em que todos são imitados "como agentes ou em atividade" (ஸ் $\pi \rho \alpha ́ \tau \tau o v \tau \alpha \varsigma \kappa \alpha i ̀ ~ \varepsilon ́ v \varepsilon \rho \gamma o \tilde{v} \tau \alpha \varsigma)$.

Ainda que haja pequenas particularidades na argumentação, teríamos as mesmas três formas para ambas as análises: a narração simples platônica

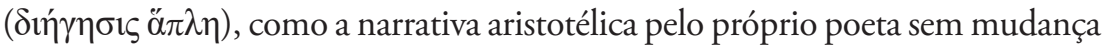

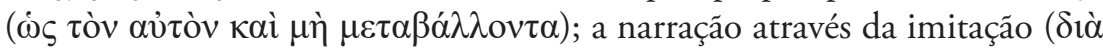

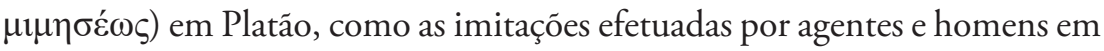

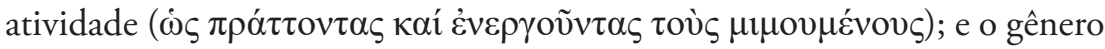
misto platônico, como a narrativa que é efetuada pelo poeta ao se tornar um

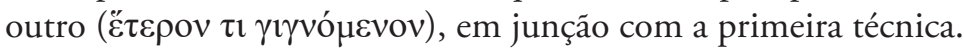

Partindo também dessa concepção dos dois filósofos, Genette em "As fronteiras da narrativa" acrescenta que, para além desse esquema entre essas formas narrativas, é preciso reconhecer o expediente da descrição como um elemento separado da narração. Para o autor:

(...) toda narrativa comporta - ainda que intimamente amalgamadas e em proporçóes muito variadas -, por um lado, representaçóes de açóes e de acontecimentos, que constituem a narração propriamente dita, e, por outro lado, representaçóes de objetos ou de personagens, que são o feito daquilo que hoje em dia chamamos de "descrição". (GENETTE, 2015, p. 58).

2 República, 392, d.

3 Poética, 1448, a, 21-24. 
Ainda que esses elementos pareçam figurar em espaços distintos, a técnica de descrição é muitas vezes confundida com a técnica de narração. Os limites entre o que é narração ou descrição são móveis (SCHMID, 2010, p. 4). Por outro lado, pode-se reconhecer uma descrição em seu sentido lato, quando, como diz Schmid, "representam estados: descrevem condiçôes, desenham imagens ou retratos, desenham meios sociais ou categorizam fenômenos naturais e sociais" . ${ }^{4}$ Assim, se nos ativermos a esse último significado, compreenderemos que a descrição é uma técnica importante para a narração, pois situa objetos, substancializa personagens, cria contrastes entre seres, entre outras possibilidades. Todas essas descrições se integram ao fio narrativo, mas também podem se deslocar do fio narrativo para ressaltar uma situação ou produzir principalmente uma caracterização.

A descrição desponta como um elemento da narrativa, como um todo, cuja função, em oposição à da narração (o modo narrativo), é meramente decorativa. Aliás, para Genette, o expediente da descrição na antiguidade figurava como um entre os ornamentos da retórica antiga. A narração incide sobre açóes e acontecimentos, enquanto a descrição incide sobre seres e objetos, tendo o primeiro uma relação estreita com o aspecto temporal, e o segundo não só parecendo suspender o curso do tempo, como também atribuindo mais relevo ao aspecto espacial na narrativa. Nesse sentido, a descrição, tal como Genette a definiu, parece contribuir mais para realçar um quadro no qual a narrativa se entranhará do que para dar sequência aos eventos de uma determinada narrativa. E, ainda que as fronteiras entre esses dois elementos da narrativa não sejam muito bem delimitadas, Genette reafirma a diferença específica entre os dois:

A diferença mais significativa talvez fosse que a narrativa restitui, na sucessão temporal de seu discurso, a sucessão igualmente temporal dos acontecimentos, ao passo que a descrição deve modular no caráter sucessivo a representaçáo de objetos simultâneos e justapostos no espaço... (GENETTE, 2015, p. 62).

Tomando essa última diferença entre narração e descrição, é possível aprofundá-la em direção a algumas particularidades na construção do enredo literário clássico.

Desde Aristóteles, o enredo segue um ideal de construção que prescreve ao seu bom funcionamento o encadeamento causal das açóes. Tal causalidade nada mais é do que o liame entre uma ação e outra. O verossímil e o necessário são modos causais do liame que determinam a boa construção do enredo. Entretanto, para além desse esquema aristotélico de construção do

4 “(...) represent states: they describe conditions, draw pictures or portraits, portray social milieus, or categorize natural and social phenomena." (SCHMID, 2010, p.5). 
enredo, é possível entrever na narrativa homérica e trágica algumas açóes que propriamente não estabelecem uma ligação forte com as ações determinantes do enredo.

Há açôes que possuem unidade em si mesmas, mas que não são as açôes que compóem a ação una aristotélica. Essas açôes mais preparam e descrevem situaçóes do que dáo sequência à consecução do enredo. A sua ocorrência dentro da narrativa aprofunda a caracterização das personagens, gera horizontes narrativos tal como um enquadramento, e aumenta a tensão antes de açóes principais; são sobretudo mais eventos do que açôes no sentido aristotélico. E, apesar de sua condição subordinada, esses eventos 5 são de suma importância, por conferirem à narrativa o espaço no qual uma ação posterior se desenrolará. Funcionam antes de tudo como pequenos eventos, gravitando em torno de açóes principais, em enredos marcados pelo encadeamento das açóes.

Descrição e evento estão intimamente ligados. Peter Klaus reconhece tal ligação como uma subordinação:

Um evento poderia entáo ser considerado como uma mudança de propriedades. No nível do texto, propriedades são representadas por descriçôes. Disso ocorre que um evento tem de levar a uma mudança de descrição. Essa mudança terá a seguinte estrutura: uma situação inicial, uma transiçáo e uma situaçáo final. (KLAUS, 1982, p. 203)

É necessário também reconhecer certa imobilidade do ponto de vista do ritmo narrativo. Essas açóes/eventos são quase estáticas na narrativa dentro do quadro geral do enredo, possuindo, porém, um desenvolvimento próprio. Tais eventos, dentre os muitos quadros estáticos presentes em um enredo, podem ser chamados de "cenas de caracteres". ${ }^{6}$ Geralmente, são acontecimentos que particularizam uma situaçáo, cujo foco pode ser, por exemplo, uma personagem em descriçóes múltiplas, individualizando-a em detrimento de outras personagens. São também acontecimentos, como já apontamos, desligados da ação central, que cumprem funçóes mais específicas - por exemplo, preparar a cena para uma ação subsequente; demonstrar qualidades particulares das personagens; e elevar, principalmente na tragédia, o páthos $(\pi \dot{\alpha} \theta \mathrm{o} \zeta)$ na sequência do enredo.

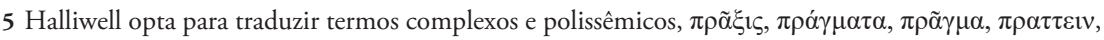
por verificar o contexto no qual eles aparecem. Entretanto, $\pi \rho \alpha ́ \gamma \mu \alpha \alpha \tau$, que é usado para a construçáo do enredo, ele o identifica com a noção de evento que adotamos aqui. Conf. Helliwell, "Action and Character", em Aristotle's Poetics.

6 Dou o nome de cena de caracteres aos quadros descritivos dentro da narrativa que, imobilizando a açáo ou dilatando o tempo narrativo, foca em personagens ou em objetos a fim de transformá-los ou ressaltá-los para a sequência narrativa. 
A principal característica de tal episódio é suspender a ação principal para que um olhar detalhado possa revelar minúcias que, dentro da sequência das ações principais do enredo, não podem ser particularizadas. Essa técnica possui um extenso desenvolvimento ao longo da história da literatura, mas o seu início em Homero já era bastante sofisticado.

Assim, com base no trabalho de Irene de Jong, Narrative in Drama: the art of the Euripide an Messenger-Speech, que demonstrou como é possível existirem trechos narrativos no teatro de Eurípides, faremos uma comparação entre algumas cenas da épica arcaica com a tragédia euripidiana. Tal comparação incide na existência de quadros narrativos também no enredo trágico. De início, precisamos afirmar em consonância com a autora que "personagens dramáticas contam estórias, por meio das quais assumem um papel de narrador". ${ }^{7}$ Somada a essa afirmação contundente, mais recentemente Barbara Goward investigou, em Telling Tragedy: narrative technique in Aeschylus, Sophocles and Euripides, ${ }^{8}$ a tragédia como narrativa, afirmando que:

(...) operando em um mesmo nível narrativo e temporal como aquele no qual a ação de uma peça toma lugar, qualquer uma das personagens dramáticas pode preencher isso, alternadamente, para suprir a funçáo de narrador, (...)” e "desta perspectiva, é evidente que não somente os óbvios elementos narrativos tal como o "discurso-mensageiro" deve ser investigado por suas propriedades narratológicas, mas todos os outros elementos em uma tragédia também, tal como prólogo, rhêsis, sticomythia, ode coral, etc. (GOWARD, 1999, p.12)

Diante dessa possibilidade, interessa-nos analisar algumas passagens da épica homérica e cotejar seu eco em uma tragédia de Eurípides para entendermos tal fenômeno.

\section{Cena de caracteres na épica homérica}

Homero, tanto na Odisseia quanto na Ilíada, revela a sua habilidade em compor cenas de caracteres. Nas duas obras, a última ação principal antecede o final da obra. Na Ilíada, a fúria ( $\mu$ ñvis) de Aquiles, que se desloca de seu primeiro alvo - Agamenon - para um segundo, extingue-se com a morte de seu antagonista no campo de batalha, Heitor. Mas a tensão ainda permanece. Aquiles detém o corpo de seu inimigo, ultrajando-o em torno do túmulo de Pátroclo e evitando que o mesmo seja glorificado pelos seus concidadáos. $\mathrm{O}$

7 Irene de Jong, (...) dramatic characters tell a story, whereby they assume the role of narrator. (JONG, 1991, p. 117)

8 Barbara Goward amplia o panorama de sua análise para além do discurso do mensageiro, analisado exaustivamente por Irene de Jong. 
ato de Aquiles enfureceu parte dos deuses, principalmente Zeus, que resolve o impasse ordenando a Aquiles devolver o corpo após o pagamento de resgate, e ao rei Príamo a dirigir-se até a tenda de Aquiles para resgatar o corpo do filho.

Tudo o que antecede a cena de encontro entre Aquiles e Príamo é produzido para elevar a tensão no episódio. $\mathrm{O}$ caráter de Aquiles é representado de forma oscilante, e o medo que toma conta de Príamo é lacerante. O encontro é descrito por um símile que produz grande efeito:

Como quando o forte desvario toma um homem, que, em sua pátria,

Tendo matado alguém, chega à casa de outros,

De um homem rico, e o estupor toma aqueles que o veem,

Assim Aquiles, tendo visto o divino Príamo, espantou-se;

E espantaram-se também os outros, olharam-se uns aos outros.

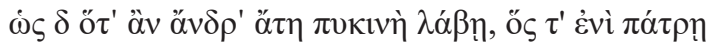

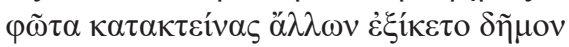

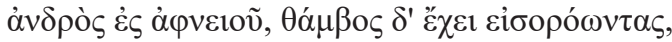

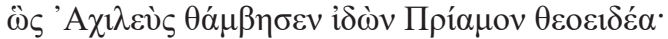

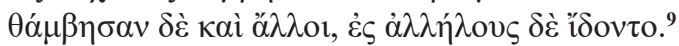

O medo de Príamo é introduzido na cena, seu rosto é semelhante ao

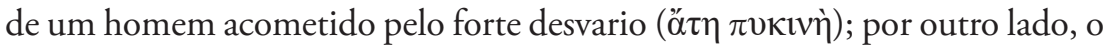
estupor $(\theta \alpha \dot{\alpha} \mu \beta \rho \varsigma)$ toma não só Aquiles como também seus companheiros que estavam em cena. $O$ verbo proveniente do estupor $(\theta \alpha \dot{\alpha} \mu \beta \eta \sigma \varepsilon v, \theta \alpha \dot{\alpha} \mu \beta \eta \sigma \alpha v)$ é repetido mais duas vezes, generalizando o olhar que dirigiam uns aos outros. Willcock menciona a inversão dos papéis: "para o homem que tinha chegado, (o papel) é de um inocente de qualquer ato de violência, enquanto o assassino é o homem sentado entre seus seguidores" (WILLCOCK, 1976, p. 271). Homero coloca em primeiro plano nessa cena o foco sobre o rosto de cada um, oferecendo-nos a dimensão exata dos olhares.

Em atitude suplicante, Príamo discursa comparando, no mesmo tom de contraste acima, ele próprio com Peleu, pai de Aquiles. Com temor de ser maltratado, lembra a Aquiles que seu pai ainda vive entre muitos, que o maltratam, não tendo quem o proteja de humilhações e vexames. Afirma também ter tido cinquenta filhos, dos quais nenhum mais vivia, todos mortos em combate. $\mathrm{O}$ contraste com a situação de Aquiles é latente: filho único e ainda vivo de seu pai. O efeito do discurso que seguia a matéria estabelecida por Hermes, a fim de convencer Aquiles, foi devastador. A próxima cena o demonstra:

9liada, Canto XXIV, v. 480/484. 
Assim disse, e nele então excitou o desejo de pranto pelo pai;

Tendo-o tocado com a mão, empurrou delicadamente o ancião.

Tendo ambos recordado, um, de Heitor, matador de homens,

Chorava sonoramente, tendo rolado diante dos pés de Aquiles,

Porém, Aquiles chorava seu pai, e novamente, o outro,

Pátroclo; e o lamento deles projetou-se pela casa.

Porém, depois que o divino Aquiles saciou-se do lamento,

E o desejo partiu-lhe do coração e dos membros,

Imediatamente alçou-se do trono, e com as mãos levantava o ancião

Comovendo-se com sua cabeça e sua barba encanecidas,

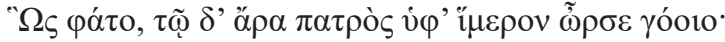

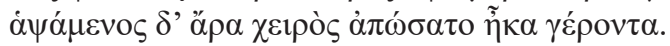

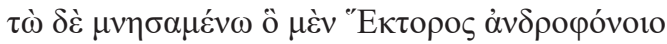

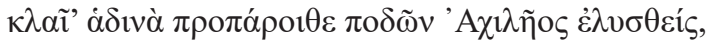

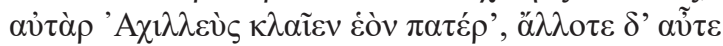

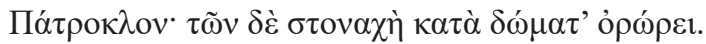

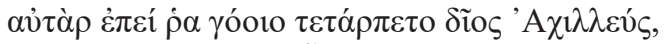

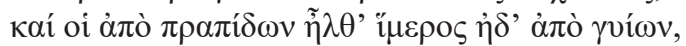

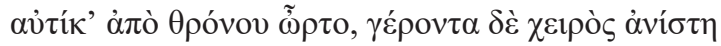

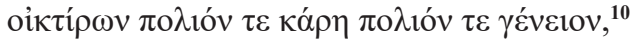

A cena descreve uma grande comoção entre os inimigos. Neste exato momento, as diferenças foram apagadas, e cada um chora por seus mortos. $\mathrm{O}$ primeiro gesto de Aquiles é distanciar o corpo do ancião que está em posição suplicante, agarrado aos seus joelhos, empurrando-o com suas mãos; sem resistência o ancião desmorona. Decorrido algum tempo (ambos os verbos são empregados no passado infectum), Aquiles, com suas mãos, contrastando com a primeira atitude, levanta o ancião para restabelecê-lo.

A ordem das coisas volta ao natural. Os gestos aqui empregados por Homero dão a plasticidade da cena. O silêncio impera. Nenhuma palavra, entre eles, dita a sequência dos gestos. Tudo segue naturalmente o movimento que vai das lágrimas ao compadecimento. Cada um com suas próprias dores, mas com sentimentos universais. A alma humana revela-se a mesma.

Entre as duas cenas anteriores, um discurso não menos emotivo é proferido por Príamo. O discurso alcança seu efeito na última cena, após a qual se seguirão novos discursos, que aumentarão a tensão. Com nitidez, as cenas acima demonstram como Homero suspende a ação para detalhar os entornos e apresentar os íntimos caracteres de suas personagens. Não há, entretanto, total imobilismo. A intercalação de discursos constrói cenas mais vívidas, mas não menos caracterizadoras.

10 Iliada, Canto XXIV, (v. 507-516). 
Outra passagem mostra-nos um pouco mais do artifício homérico de modo ainda mais sofisticado. Agora, já na Odisseia, no canto V, a deusa Atena solicita ao seu pai que Odisseus possa retornar a Ítaca, deixando a ilha que habita com a ninfa Calipso. Não mais pelo olhar onipotente do poeta mas pelo olhar do mensageiro Hermes, vemos duas cenas que contrastam entre si e preparam uma cena de despedida entre Odisseus e Calipso:

mas quando chegou à ilha que está longe, lá tendo chegado do mar cor de violeta, à terra ia, até que chegou a uma grande gruta, na qual a ninfa de belas tranças habitava, e ele a encontrou lá dentro. Um grande fogo sobre a lareira ardia, ao longe um odor De lenha de cedro e de incenso exalou pela ilha, Espalhando-se, e dentro ela, cantando com linda voz, Lançando-se sobre um pano dourado, uma peça urdia. Um arbusto em torno da caverna cresceu frondoso: Amieiros, choupos e ciprestes perfumados. Lá, aves de asas compridas construíam ninhos: Corujas, falcóes e corvos marinhos tagarelas, Às quais as obras marítimas proveem.

E em torno da própria gruta funda se estendera Uma vistosa vinha, com frondosos cachos de uvas. Próximo, quatro fontes fluem com água clara, Vizinhas percorrendo uma próxima da outra. Em torno, suaves campos de violeta e de aipo Floresciam. Ali, então, um imortal também, chegando, Contemplaria, tendo visto e se deleitado, em sua mente.

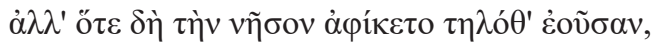

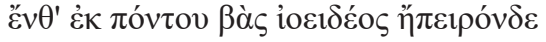

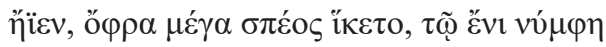

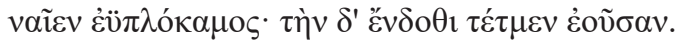

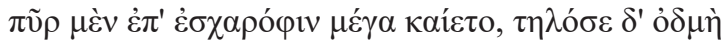

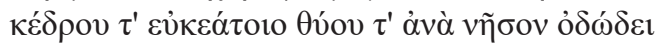

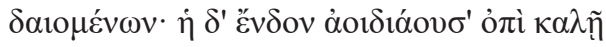

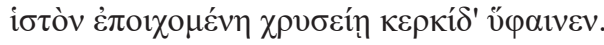

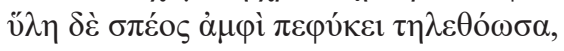

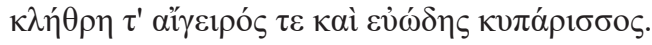

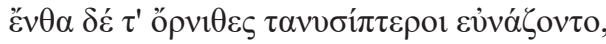

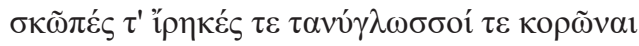

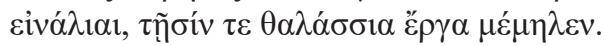

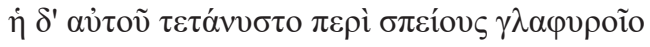

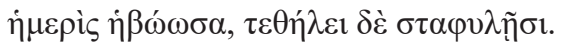

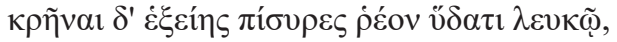

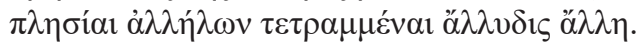




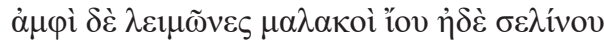

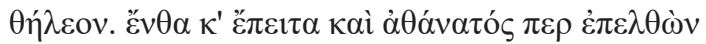

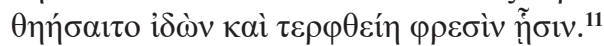

Hermes é o nosso guia. Vemos o que ele vê. O poeta se exime de descrever a passagem por si mesmo. Entre prados, pássaros e riachos, o antro é descrito com simplicidade. A descrição do entorno, sem exageros, pode ser considerada o início do impulso bucólico. ${ }^{12}$ Tudo está em perfeito estado de ânimo. Calipso, sem percebê-lo, trabalha no tear, externando seu contentamento com linda voz (ò $\pi \grave{~} \kappa \alpha \lambda \tilde{\eta})$.

Homero, nesse trecho, mostra-se um mestre do contraste. Não só a mensagem de Hermes se revelará duríssima para Calipso, como também, na cena que sucede a essa passagem, o poeta em breves versos representa o mundo oposto ao da deusa, o mundo de Odisseus:

Entấo, não encontrou lá dentro Odisseus magnânimo, Mas esse, estando sentado, chorava em ponto afastado, Puindo o coração com lágrimas, lamentos e dores, Espreitava o límpido mar, vertendo lágrimas.

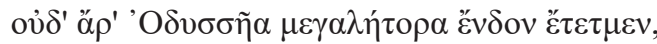

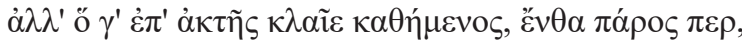

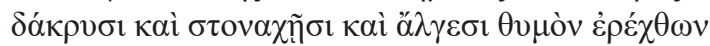

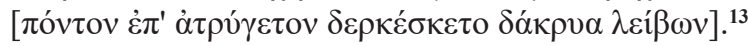

O antagonismo entre as duas cenas alcança o máximo grau nesta descrição. Só conseguimos compreender essas cenas em sua completude, se alocarmos uma ao lado da outra, como faz o poeta. Ao contrário da cena da Ilíada, essa não possui nenhum diálogo intercalado entre elas. A comparação entre as duas imagens é imediata e revela profundamente o universo emocional das personagens. A cisão foi preparada antes do próprio discurso de Hermes. Cada personagem já habitava mundos completamente diferentes.

Tanto na Ilíada quanto na Odisseia, constatamos momentos que correspondem a genuínas cenas de caracteres. A Odisseia possui mais cenas como essas, por não estar alocada no campo de batalha, onde quase tudo é

11 Odisseia, Canto V, (v. 55-74).

12 Boléo, definindo o cenário pastoril dos idílios bucólicos, nos diz que "é relativamente simples e quase uniforme, o que não é para admirar, atento ao carácter convencional da bucólica. Ele nâo comporta vastas perspectivas: um rochedo, a espessura verde de um bosquezinho, constituem o seu fundo ordinário; uma fonte, um regatozinho, ocupa geralmente o centro; nas suas margens estende-se um tapete de erva verde; alguns pinheiros, olmos, choupos, carvalhos, compóem uma abóbada de folhagem; as aves chilreiam nos ramos, os insectos sussurram, a água murmura correndo sobre as pedras." (BOLÉO, 1936, p.54).

13 Odisseia, Canto V, (v. 81-84). 
ação. A interrupção da ação não é completa, mas suspende em certa medida a mobilidade, a fim de que possa produzir maior emoção na sequência narrativa.

\section{Cenas de caracteres na Ifigênia em Aulis de Eurípides}

Tal como na cena de caracteres em Homero, este mesmo artifício, produzir emoção e caracterização, foi também empregado pelos trágicos em suas narrativas. Na tragédia, a sequência de imagens não é tão flagrante, como na épica homérica. A dificuldade reside em apresentar cenas que náo destoem da ação principal no palco, mas que ao mesmo tempo adentrem em planos que denunciam laços afetuosos, confidências, gestos e emoçóes. Tais cenas podem ser representadas por uma personagem, executando monodias líricas, ou por duas ou mais personagens em diálogos que se conectam para produzir momentos quase estáticos na ação trágica.

Entre os três principais trágicos, Eurípides mostrou-se um grande condutor desse pathos $(\pi \alpha \dot{\theta} \theta \text { os })^{14} \mathrm{em}$ suas tragédias. Suas cenas são trabalhadas para momentos específicos dentro de seus enredos. Cada personagem, assim que ela entra em cena, possui uma carga emotiva que é descarregada no enredo.

Em sua Ifigênia em Áulis, duas cenas são apresentadas para se entrelaçarem com o momento crucial da peça: o discurso de aceitação do sacrifício, pelo qual Ifigênia, filha de Agamenon, seria morta. As duas cenas apresentam Ifigênia em relaçáo afetuosa com o pai que em um primeiro momento apresentava-se atordoado por ter de fazer o sacrifício e em um segundo momento por já ter decidido fazê-lo. Logo em sua chegada ao acampamento, Ifigênia se manifesta:

Ó mãe, tendo corrido a sua frente - náo te encolerizes -

Em torno ao peito de meu pai lançarei o meu peito.

Eu desejo, ó pai, aos teus peitos,

Tendo me adiantado, lançar-me, por tanto tempo:

Reclamo, pois, seu olhar - não te encolerizes -

$\tilde{\omega} \mu \tilde{\eta} \tau \varepsilon \rho, \dot{v} \pi \circ \delta \rho \alpha \mu$ oṽ $\alpha \dot{~} \sigma^{\prime}-\dot{\rho} \rho \gamma 1 \sigma \theta \tilde{\eta} 1 \varsigma \delta \grave{\varepsilon} \mu \eta \dot{-}$

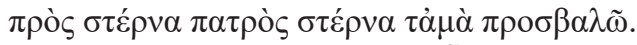

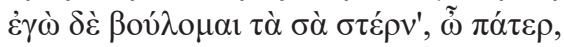

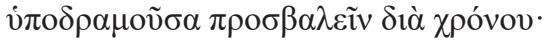
$\pi \mathrm{o} \theta \tilde{\omega} \gamma \alpha \grave{\alpha} \rho$ ö $\mu \mu \alpha<\delta \grave{\eta}>\sigma o ́ v \cdot$ ỏ $\rho \gamma 1 \sigma \theta \tilde{\eta} 1 \varsigma \delta \grave{\varepsilon} \mu \eta^{15}$

14 É necessário esclarecer que o termo páthos ( $\pi \alpha \dot{\theta} \theta \mathrm{o} \varsigma$ ), neste trecho, corresponde não à definição de um dos momentos do enredo aristotélico que se concentra especificamente sobre o momento da ação catastrófica, mas ao uso retórico do discurso que atravessa todo o enredo, denunciando estados emocionais de suas personagens. A essa palavra podemos atribuir como sinônimo o sentido de emoção.

15 Ifigênia em Áulis. Eurípides. (v. 631-637). 
O desembarque, naquele momento, indesejado por Agamenon, ocorre não obstante suas tentativas para impedir a chegada de sua filha e de sua esposa, Clitemnestra. A cena é patética ao se referir à expressão do amor de uma filha a um pai. O tema também é universal. No primeiro e no último verso, a mesma preocupação é atestada para os pais, já que Ifigênia não pretende encolerizá-los com o seu ato. A obediência define o estado de espírito de Ifigênia. Mas em uma ação tão patética, os sentimentos parecem que não se correspondem. Ifigênia requisita, reclama o olhar do pai, que talvez estivesse alhures, por náo poder suportar o encargo que a deusa Ártemis lhe havia atribuído, sacrificar sua filha.

Depois desse primeiro encontro entre as duas personagens, outro de mais intensidade acontecerá entre pai e filha. No segundo, o estado emocional de Agamenon era diferente daquele primeiro. O rei já estava decidido a sacrificar sua filha em prol da causa grega. Ifigênia, por outro lado, já sabia que estava ali para ser sacrificada. Tal como a situação, o tom do discurso é outro, mas evoca novamente cenas familiares entre os dois:

$\mathrm{Eu}$, a primeira, te chamei pai e tu a mim, filha:

A primeira que pôs em teus joelhos o corpo,

Belas carícias dei e recebi em troca.

A tua fala era esta: "entáo eu, ó filha, a ti

Feliz, na casa de um varão, verei,

Vivendo e florindo de modo digno de mim!

O meu, por sua vez, era (estando agarrada em seu

Joelho, no qual agora toco com a máo) este:

E então o que eu te dizia? Por acaso, velho receber-te-ei

Em queridas hospitalidades de minha casa, ó pai,

Restituindo-lhe os ternos cuidados contra as penas!

Dessas palavras eu tenho lembrança,

Mas tu já te esqueceste, e matar-me desejas.

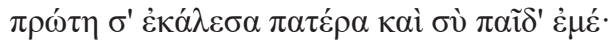

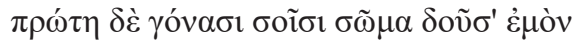

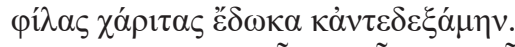

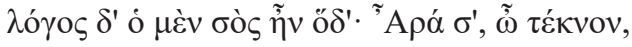

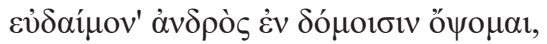

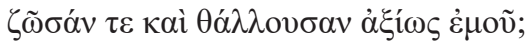

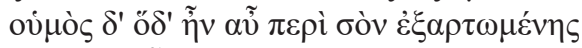

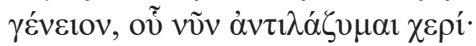

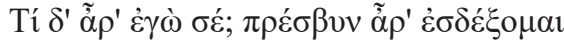

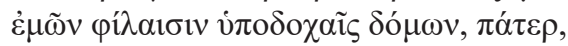

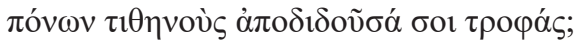


Por meio de discursos analépticos, Ifigênia recria o ambiente feliz e distante de sua relação com o pai, em momentos íntimos. A primeira parte do discurso prolonga a situação, na qual ela se encontra neste exato momento. Sabemos que ela está postada como uma suplicante, agarrada aos joelhos do pai, e ironicamente ela rememora o mesmo gesto, como a primogênita, no qual recebia carinhos do pai.

Seu discurso é bem específico em suas partes, mas forma um todo muito bem definido em oposição à situação atual. As partes desse discurso dispóem as três idades: como criança, noiva e mulher mais velha que retribui os cuidados de uma boa criaçáo. Essa disposiçáo evoca a ordem natural da vida que estava prestes a ser quebrada. Os momentos evocados pela personagem perfazem uma relação de harmonia e sucedem-se como quadros desejáveis de uma existência serena. Por fim, o discurso de Ifigênia traz à tona imagens existenciais, que não lhe pertencem mais, além de evocar também a idade a que o próprio pai jamais chegaria, a velhice.

As descrições, no discurso da personagem, do trecho acima são claras ao rememorar cenas da vida íntima entre o pai e a filha, além de dimensionar a dor da personagem em um momento crucial da narrativa. Diferentemente do exemplo que analisamos na Odisseia, esta cena é caótica. Os quadros de concórdia familiar entram em choque com o acampamento militar, no qual as duas personagens se encontram. Mas essa situação só pode ser inferida. A descrição do lugar em que eles estão não se manifesta em seu discurso, mas está dispersa pelo enredo da peça. As vantagens da épica em relação à tragédia residem no olhar do narrador que pode descrever cenas completas, enquanto a tragédia só pode conectar descrições tais como aquelas com doses de bucolismo, em passagens tal como nos cantos líricos entoados por algumas personagens.

Na mesma obra e na sequência dessas duas cenas, Ifigênia entoa uma monodia lírica que busca a causa de seus tormentos, chegando até Páris e inocentando indiretamente seu pai Agamenon da responsabilidade do sacrifício:

Jamais tu deveste, entre

Bois, o pastor Alexandre,

Tendo-o alimentado, ter criado

Entre água límpida, onde fontes

Das ninfas jazem,

16 Ifigênia em Áulis. Eurípides. (v. 1220-1232). 
Um prado germinante entre brotos

Recentes e flores de rosas

Floresciam e recolhiam-se jacintos para deusas.

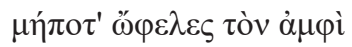

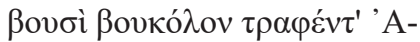

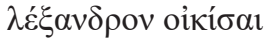

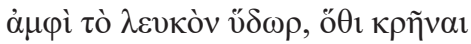

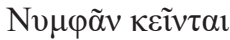

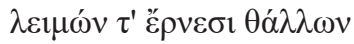

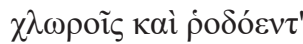

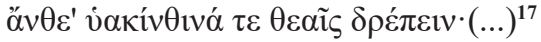

No canto entoado por Ifigênia, ao evocar o causador dos males presentes e vindouros dirigino-se a Príamo, o locus amoenus ${ }^{18}$ é o que dá o tom de contraste entre o lugar plácido, onde Páris foi nutrido, com o acampamento militar, no qual ela se encontra agora. Os mesmos elementos que encontramos na descrição homérica aqui também estão presentes, ainda que a descrição contenha um tom emocional, que destoa do imobilismo encontrado na cena homérica. A descrição da paisagem tem por função aprofundar o conflito iminente, opondo lugares, pessoas, situações.

$\mathrm{O}$ que se destaca em todas essas cenas analisadas é sobretudo o grau de imobilismo que as define como cenas de caracteres. Ainda que não haja a completa separação entre as açóes principais e esses eventos, apreendemos de sua composição um nível de dramaticidade que influenciará a ação subsequente, por vezes mais contundente dentro do processo narrativo.

\section{Considerações finais}

A descrição é uma propriedade da narrativa que potencializa tudo o que habita o mundo narrativo. Entretanto, ao considerarmos os dois modos de elocução narrativa apresentados por Aristóteles e Platão, torna-se necessário ressaltar alguns pontos de divergência entre a épica e a tragédia.

Homero sem maiores problemas, como narrador, usa o expediente da descrição para ressaltar objetos, situações e personagens. A descrição é executada ou pelo próprio narrador, como no episódio de Aquiles, ou através de uma personagem, como no caso do mensageiro dos deuses, Hermes.

17 Ifigênia em Áulis. Eurípides. (v. 1291-1299).

18 O Locus Amoenus é um lugar comum na literatura. Segundo Curtius, "é uma bela e ensombradada nesga da Natureza. Seu mínimo de apresentação consiste numa árvore (ou várias), numa campina e numa fonte ou regato. Admitem-se a título de variante, o canto dos pássaros e flores, quando muito o sopro do vento." (CURTIUS, 1957, p. 202). 
A composição dramática das tragédias clássicas gregas está profundamente influenciada por essa técnica, pelo fato de que ambas as poesias, épica e dramática, não só possuem um forte lastro de poesia oral, mas também apresentam uma continuidade em termos de técnica, transpostas para o texto dramático sem maiores problemas.

Entretanto, até por uma impossibilidade de um narrador no drama clássico grego, a descrição é um expediente executado por uma personagem que, por habilidade do poeta, pode descrever situaçóes, paisagens, objetos, e principalmente caracterizar personagens dramáticas. Essa personagem produz, pelos discursos, eventos que completam o enredo, sem diretamente incidir sobre as açóes principais que o compóem, produzindo assim quadros estáticos dentro do plano geral do enredo. Esses eventos são subsidiários em relação

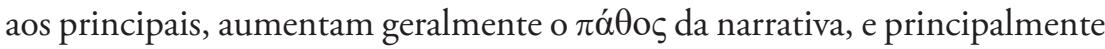
moldam as personagens em quadros íntimos.

A técnica da descrição é meio pelo qual esse evento é constituído e, desde Homero, tem sido um expediente narrativo de grande importância não só para apresentar coisas ou situaçóes, mas também para emoldurar personagens em cenas de caracteres.

Referências bibliográficas

ARISTOTE. Poétique. Texte établi et traduit par J. Hardy. Paris: Les Belles Lettres, 2002.

BOLÉO, Manuel de Paiva. O bucolismo de Teócrito e Vergílio. Coimbra: Biblioteca da universidade, 1936.

CURTIUS, Ernest R. Literatura europeia e idade média latina. Rio de Janeiro: Instituto Nacional do Livro, 1957.

EURIPIDES. Euripidis fabulae: Iphigenia Aulidensis, ed. J. Diggle, vol. 3. Oxford: Clarendon Press, 1994.

GENETTE, G. Figuras II. Trad. Nícia Adan Bonatti. São Paulo: Estação Liberdade, 2015.

GOWARD, Barbara. Telling Tragedy: narrative technique in Aeschylus, Sophocles and Euripides. London: Gerald Duckworth \& Co. Ltd, 1999.

HALLIWELL, Stephen. Aristotle's Poetics. Chicago, The University Chicago Press, 1998. 
HOMERO. Iliada. Texto critico, traducción y notas por Luis M. Macía Aparicio. Vol. I, II, III y IV. Madrid: CSIC, 2007.

HOMERO. Odyssea. ed. P. von der Momerum. Helbing \& Lichtenhahn, 1962.

JONG, Irene J. F. de. Narrative in Drama: The Art of the Euripidean Messenger Speech. Leiden: Brill, 1991.

KLAUS, Peter. Description and Event in Narrative. Copenhagen: Orbis Litterarum, 1982, 37, 201-216.

PLATO. La République. ed. bilingue. Trad. É. Chambry. Paris: Belles Lettres, 1934.

SCHMID, Wolf. Narratology: an introduction. New York: Walter de Gruyter GmbH \& Co. KG, 2010.

WILLCOCK, Malcolm M. A companion to the Iliad. Chicago: University of Chicago Press, 1976.

Marco Valério Classe Colonnelli. Professor de Letras Clássicas na Universidade Federal da Paraíba. Possui graduação em Filosofia pela Universidade Presbiteriana Mackenzie (2002), mestrado em Letras pela Universidade Federal da Paraíba (2009) e doutorado em Letras pela Universidade Federal da Paraíba (2015). Atua nas áreas de língua grega, tradução e estudos de retórica e oratória gregas antigas. E-mail: mcolonnelli@hotmail.com 